\title{
Roles And Responsibilities Investigator In Investigation of Illegal Mining In Society Mining for Environmental Sustainability
}

\author{
Kurniawan Daeli $^{1}$ and Rakhmat Bowo Suharto ${ }^{2}$
}

Abstract. The problem in this research are: setting illegal mining in the legislation and the role of the investigator in the investigation of a case of illegal mining. Based on the results of the study concluded that: setting illegal mining in the legislation is in terms of penal policy within the meaning of penal law enforcement policy includes several stages, including the stage of formulation, application phase and the execution phase, but in relation to this, the discussion will be focused on the application phase for the implementation of Act No. 4 of 2009 on the eradication of illegal mining, which happened recently. The role of the investigator in the investigation of illegal mining case is Supervisors investigators have experience and knowledge are qualified when she served so supervisory investigator. In addition, the supervisory investigator is also expected to continue to follow the development of crime which took place at the time. Thus, the supervisory investigator will not be lacking in the process of analyzing the monitored object. Supervisory investigator to conduct surveillance should be independent and not affected by the intervention whatsoever. The conclusion of this study is the context of law enforcement against Act No. 4 of 2009 has experienced a bottleneck, so that its application does not reflect a sense of justice for the perpetrators of violations in the field of illegal mining. Supervision of the investigation basically already done well with the basic rules Police chief Regulation No. 12 of 2009, but for the disciplinary action is not implemented.

Keywords: Roles, Responsibilities, Investigator, Investigation, Illegal Mining, Mining

\section{Introduction}

Mineral resource is a natural resource that is not renewable or non-renewable resource, meaning that once the excavated material dredged it will not be able to recover or return to its original state. ${ }^{3}$ Indonesia itself was awarded the abundant natural resources including minerals mining and Indonesia have a high dependence on the utilization of mining minerals such as capital construction. ${ }^{4}$ Often mining in Indonesia has a negative impact triggered the criminal offense of illegal mining or mining called without permission. Unlicensed mining is mining or quarrying activities carried out by people or companies without a permit and using the principles of good mining and correctly according to applicable regulations. ${ }^{5}$ So legal and illegal are not

\footnotetext{
${ }^{1}$ Student of Master of Law, Universitas Islam Sultan Agung Semarang and Member of Indonesian National Police, email kdaely@gmail.com

${ }^{2}$ Faculty of Law Universitas Islam Sultan Agung

${ }^{3}$ Ali Yafie, 2006, Merintis Fiqh Lingkungan Hidup, Jakarta: Ufuk Press, p.141.

${ }^{4}$ Adrian Sutedi, 2011, Hukum Pertambangan, Jakarta: Sinar Grafika, p.103

5 Suciati Noor, "Delik Khusus Illegal", http://www.academia.edu/9707685/Delik_khusus_Penambangan_llegal, accessed on January 3, 2019.
} 
only categorized on there was consent, as authorized any potentially illegal mining in other forms which are criminalized in the Law on Mineral and Coal Mining. ${ }^{6}$

Based on Act No. 4 of 2009 on Mineral and Coal, mining in Indonesia is set in the mining area, the central government appointed a mining region in the national spatial plan after consultation with parliament and local government. A mining areas categorized into five types of minerals are: radioactive, metallic minerals, coal, nonmetallic and / or rock.

Mining areas categorized and confirmed a region Mining License (WIUP). A Mining Business License (IUP) can only be granted to mining companies for locations that have been designated WIUP her. Mining permit holder does not have ownership of the land allocated to the area, and were only allowed to take one type of mineral in their concession area and is not automatically to exploit other minerals in the same concession.

The act which is punishable by criminal law are actions that absolutely must meet the formal requirements, which match with the formulation of the Act which has been established by the Penal Code and other regulations dimensional criminal, and has elements of material that is contrary to the ideals -cita the community association or by a short word of a trait or a crime against the law. ${ }^{7}$

Legal and illegal miners who are both working but there is a legal test that distinguishes environmental impact associated with the environment, while the illegal no AMDAL test so that it is risky to damage the environment. Environmental impact assessment (AMDAL) is a study of major and significant impacts of a business and / or planned activities on the environment necessary for the decision making process regarding business and / or activity. AMDAL regulations clearly asserts that the AMDAL is one of the conditions of licensing, where the decision makers should consider the results of environmental impact studies before granting license / activity. AMDAL is used to make decisions about the organization / business licensing and / or activity. Illegal mining activities are causing environmental damage is also regulated in Act No. 32 of 2009 on the Protection and Environmental Management. In addition, legislation related to illegal mining and environmental protection one of them is Act No. 41 of 1999 on Forestry, as amended by Act No. 19 Of 2004 concerning the Stipulation of Government Regulation in lieu of Act No. 1 Of 2004 on amendments to the Act No. 41 of 1999 on Forestry to become Law.

based on The background outlined above, the issues to be discussed in the writing of this study are: 1) How will the illegal mining in the legislation? 2) What is the role of the investigator in the investigation in the case of illegal mining?

\section{Research methods}

This paper is a type of practical legal research is to conduct research on the field of law enforcement, especially the crime of illegal Minning mineral and coal. Legal research in

6 Rahma Ismayanti, “Permasalahan Kesehatan Lingkungan di Indonesia" dalam https://www.academia.edu/9001147/Permasalahan_Kesehatan_Lingkungan_di_Indonesia, accessed on 3 Januari 2019.

7 Moeljatno, 1983, Perbuatan Pidana dan Pertanggungjawaban Dalam Hukum Pidana: First Ed., Bina Aksara, Yogyakarta, p.24-25. 
relation to practical legal research, as written by Peter Mahmud Marzuki that legal research is a process of finding the rule of law, principles of law, and the legal doctrines in order to address the legal issues at hand. ${ }^{8}$

The method used is the approach of law (statute approach); case approach; and the conceptual approach. Approach to legislation and case-based approach used to assess the legal sanction of a criminal offense of illegal Minning. While the approach used to analyze the application of the concept of law in criminal acts of illegal Minning and Its Problems. Legal materials have been collected was analyzed by steps as follows: the first step, analyzing the legal concept of illegal Minning along with the doctrine that developed in the criminal law, as a second step, is to analyze several court decisions related to the application of the concept of law enforcement in the field of illegal Minning.

\section{Results and Discussion}

\subsection{Settings Illegal Mining In Legislation}

Countermeasures to events or cases related to illegal mining, enforcement efforts against crime shows in the field of illegal mining by using a policy of criminal (penal policy). ${ }^{9}$ According Sudarto provide a definition of "penal policy" out of the corner of the goal, which is to realize the penal legislation in accordance with the circumstances and the situation at a time and in the years to come. ${ }^{10}$ In terms of penal policy within the meaning of penal law enforcement policy includes several stages, including the stage of formulation, application phase and the execution phase, but in relation to this, the discussion will focus on the application phase for the implementation of Act No. 4 of 2009, concerning the eradication criminal illegal mining, which happened recently.

In terms of criminal law enforcement (investigation of cases of illegal mining) refers to the operationalization of the legislation by a criminal law enforcement agencies in an effort to overcome and eradicate crime in the area of illegal Minning. Operasionalisasai was done through the criminal justice process (criminal justice proces) ${ }^{11}$. Which required a process of labor law enforcement officers in examining the alleged perpetrators of crimes to ascertain whether or not the perpetrator guilty legally concerned. At this stage of the investigation, is a process, namely the investigation phase, investigation, prosecution, until the stage of the determination of punishment or sentencing judge.

In the criminal justice system sebagimana described in Act No. 8 of 1981, of the Code of Criminal Procedure, a criminal justice system as law enforcement officers, including: Police as investigators / Civil Servant Investigators Specific, attorney as prosecutor and akim as breakers against someone who does crime in the strict sense. Law

\footnotetext{
${ }^{8}$ Peter Mahmud Marzuki, 2005, Penelitian Hukum, Prenada Media, Jakarta, p. 35.

${ }^{9}$ In the context of law enforcement needed a policy or "penal policy", see in Barda Nawawi Arief, 2001, Issues Law Enforcement and Crime Prevention Policy, Bandung, Citra Aditya Bakti, p. 73.

${ }^{10}$ Sudarto, 1983, Hukum Pidana dan Perkembangan Masyarakat; Kajian terhadap Pembaharuan Hukum Pidana, Sinar Baru, Bandung, p. 109

${ }^{11}$ Hagan, sebagaimana disitir oleh Romli Atmasasmita, 1996, Sistem Peradilan Pidana: Perspektif Eksistensialisme dan Abolisionisme, Bina Cipta, Bandung, p. 14.
} 
enforcement in a broad sense, namely: Police as investigators / Civil Servant Investigators particular, as the Attorney Prosecutor and Judge as the breaker, plus Advocates and Penitentiary. Prisons as an institution that run and maintain and supervise the convict being and for running the verdict.

In law enforcement related to illegal mining case has been experiencing a fact or phenomenon that is not in accordance with the principle of court proceedings, "a simple, quick and inexpensive" still far from expectations.

\subsection{Investigators role in Investigation of Illegal Mining Case}

Indonesia as a legal state, a logical consequence of the need for an institution that is able to oversee enforcement. Not only capable, in the implementation of the tasks of the police, also expected in each handling criminal cases to be resolved optimally.

To determine the extent of the optimization of the role of the investigator in the criminal investigation process, it must first be able to measure the performance of police investigation.

Illegal mining not just limited to the regulation of mining regulations violations, but also violations of other regulations related to mining, such as forestry and environmental regulations. Mining who conduct their activities in the forest areas of the ban, such as protected forests or environmentally damaging activities is also an illegal mining.

In the Field Manual (Juklap) handling criminal offense mining (illegal mining) Police even mentioned that illegal mining include: ${ }^{12}$

- Mining activities without a license at all as stipulated in Act No. 4 of 2009 on mineral and coal mining that term refurbished / replaced with (IUP, IPR, IUPK).

- Mining activities with the permission of the dead or ended, both ends due to be returned, canceled, or expired.

- Mining activities outside of the area or beyond the point coordinates specified in the permit granted

- Mining activities using licenses that are not in accordance with the designation.

In order to support the Priority Program Police are largely a matter of detectives (disclosure completion of the cases to eradicate illegal mining) by improving the investigator, spur change in mindset and culture set the national police and hold the center of the police service in various centers of public activity, the supervisors investigators expected to be able to work with better than what has been done before. This can be supported with respect to some crucial in order to continue the trust building that has become the first stage of a grand strategy to partnership building in phase 2 are currently underway. ${ }^{13}$

\section{Human Resources}

- Supervisory investigators have experience and knowledge are qualified when she served so supervisory investigator. In addition, the supervisory investigator is also

\footnotetext{
12 Niken Astiningrum Triasbudi, "Juklap Penanganan Tindak Pidana Pidana Pertambangan" dalam https://www.scribd.com/doc/237080870/Juklap-penanganan-Tp-Pertambangan, accessed on January 2, 2019

${ }^{13}$ Mabes Polri. 2008. Naskah Sementara Pedoman Pengawasan Penyidikan
} 
expected to continue to follow the development of crime which took place at the time. Thus, the supervisory investigator will not be lacking in carrying supervised object analysis process.

- Supervisory investigator to conduct surveillance should be independent and not affected by the intervention whatsoever.

- Supervisory investigators dare to recommend sanctions in order to make Polri professional, modern and immoral.

- Supervisory Police investigators are members who obey the code of professional conduct and clean of violations Police, thus the supervision performed may be maximal.

Facilities and infrastructure

- Police Regulation reinforced existing guidelines for the supervision of the investigation.

- There is a special budget provision under surveillance investigation and accommodation in the examination in order to control the investigation.

- There are special accommodations for supervisory investigator associated with space and hardware instruments in his work.

\section{Closing}

\subsection{Conclusion}

- The context of law enforcement of the Act No. 4 of 2009 has experienced a bottleneck, so that its application does not reflect a sense of justice for the perpetrators of violations in the field of illegal mining.

- Supervision of the investigation basically already done well with the basic rules Police chief Regulation No. 12 of 2009, but for the disciplinary action is not implemented. Disciplinary sanctions implemented only if deemed necessary. On the other hand investigators deemed unable to handle the case in question, the supervisors investigators are able to advise employers to take any investigator who watched over the case and replace the investigator who do abuse.

\subsection{Suggestion}

- Act No. 4 of 2009 need amendment or change, so that this legislation is effective and beneficial for the community and achieve a sense of justice.

- Based on the existing state of the investigation supervision at this time, then the Police should make efforts to increase the: Human Resources, Endorsement software, Procurement infrastructure, Strengthen the integrity of the supervisory investigator.

\section{Bibliography}

[1] Ali Yafie, 2006, Merintis Figh Lingkungan Hidup, Jakarta: Ufuk Press

[2] Adrian Sutedi, 2011, Hukum Pertambangan, Jakarta: Sinar Grafika 
[3] Barda Nawawi Arief, 2001, Masalah Penegakan Hukum dan Kebijakan Penanggulangan Kejahatan, Bandung, Citra Aditya Bakti

[4] Hagan, as Romli Atmasasmita, 1996, Sistem Peradilan Pidana: Perspektif Eksistensialisme dan Abolisionisme, Bina Cipta, Bandung

[5] Mabes Polri. 2008. Naskah Sementara Pedoman Pengawasan Penyidikan

[6] Moeljatno, 1983, Perbuatan Pidana dan Pertanggungjawaban Dalam Hukum Pidana : Cetakan Pertama, Bina Aksara, Yogyakarta

[7] Peter Mahmud Marzuki, 2005, Penelitian Hukum, Prenada Media, Jakarta

[8] Sudarto, 1983, Hukum Pidana dan Perkembangan Masyarakat; Kajian terhadap Pembaharuan Hukum Pidana, Sinar Baru, Bandung 